
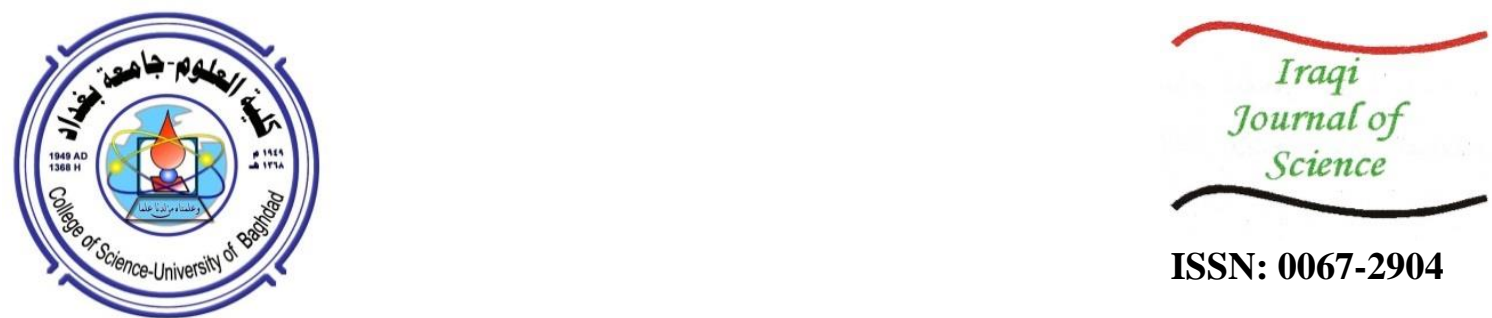

ISSN: 0067-2904

\title{
The Effect of Nano-Zinc Oxide and Nano-Titanium Dioxide on Inhabitation of Ochratoxin A
}

\author{
Layla R. Al-Saji*, Ahmed I. Al-Nazzal \\ Food Science Department, Collage of Agriculture, Tikrit University, Tikrit, Salah Eldeen, Iraq \\ Received: $17 / 1 / 2021$ \\ Accepted: 13/8/2021
}

\begin{abstract}
The experiment was conducted at the Agricultural Research Office in Baghdad during July 2020 to test the ability of nanomaterials $\left(\mathrm{ZnO}\right.$ and $\left.\mathrm{TiO}_{2}\right)$ to inhibit ochratoxin A, which is produced by a number of microbiology (fungi) including: Aspergillus ochraceus, A. niger, ,A. steynii, A. carbonarius, Pencillume verrucosum and P. nordicum. The standard ochratoxin A, with known concentration, was treated with different concentrations of nanomaterials $(20,40,60$, and $80 \mathrm{ppm})$ and two different particle sizes of nanoparticles approximately $(15 \mathrm{~nm})$ and $(70 \mathrm{~nm})$ for each $(\mathrm{ZnO})$ and $\mathrm{TiO}_{2}$; with 16 transactions. Through an examination of the HPLC, the results showed that all transactions led to a noticeable inhibition in the concentration of ochratoxin $\mathrm{A}$, and the highest inhibition rate was for $\mathrm{ZnO}$ nanoparticles with particle-size $(70 \mathrm{~nm})$ and $80 \mathrm{ppm}$ concentration, where the inhibition rate was $99 \%$. In other hand, the $\mathrm{TiO}_{2}$ nanoparticles with particle-sized $(70 \mathrm{~nm})$ and the concentration $(80 \mathrm{ppm})$ were followed by $95 \%$.
\end{abstract}

Keywords: $\mathrm{ZnO}$ nanoparticle, $\mathrm{TiO}_{2}$ nanoparticle, Ochratoxin A

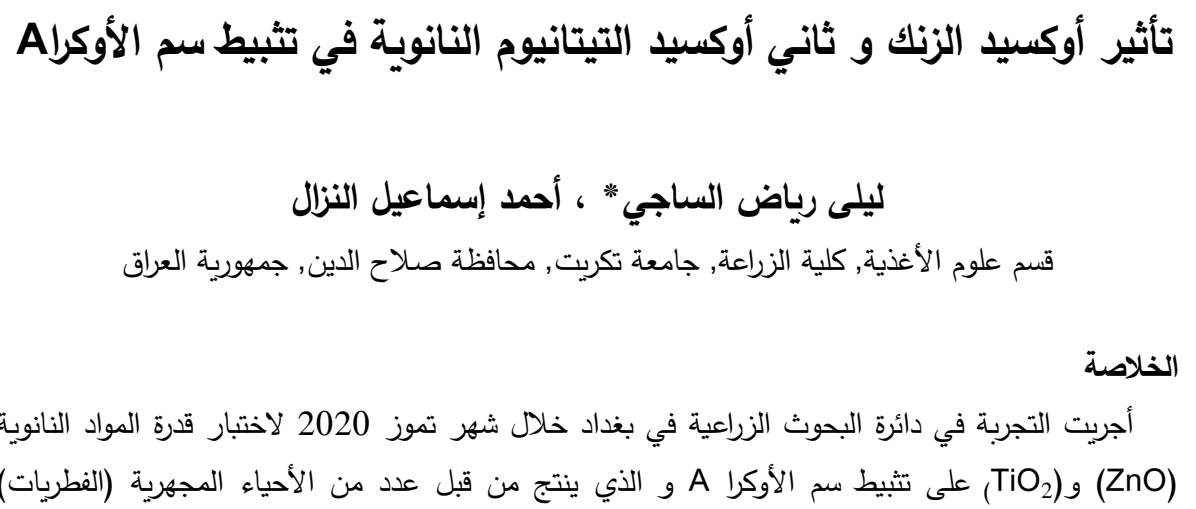

Aspergillus ochraceus, A. niger, ,A. steynii, A. carbonarius, Pencillume : منها .verrucosum and P. nordicum

تمت معاملة سم الأوكرا A القياسي معلوم التركيز مع تراكيز مختلفة من المواد النانوية و كانت كالآتي:(20),

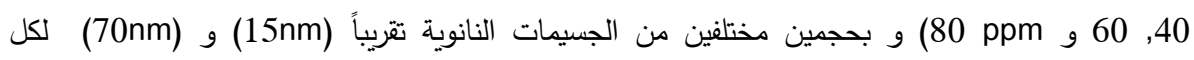

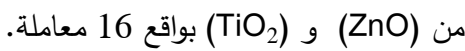
و من خلال الفحص بجهاز الـ(ZnLC) و (HPLC)، بينت النتائج أن جميع المعاملات أدت إلى تثبيط ملحوظ في تركيز

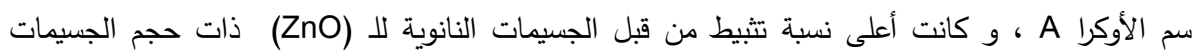




$$
\begin{aligned}
& \text { (70nm) و بتركيز (80pm) حيث كانت نسبة التثبي 99\%، جائت بعده الجسيمات النانوية لا (TiO) }
\end{aligned}
$$

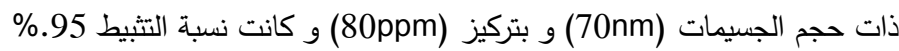

\section{Introduction:}

In a variety of disciplines, such as food science, toxicology, applied and analytical chemistry, veterinary sciences, mycology, plant science and agriculture, mycotoxins are an important concern [1]. Ochratoxins group is one of the most studied mycotoxins, containing ochratoxins A, B, C and TA [2].

In the ochratoxin group, ochratoxin A (OTA) is highly toxigenic, chemically referred to as 7 (L- $\beta$-phenylalanyl-carbonyl)-carboxyl-5-chloro-8-hydroxy-3,4-dihydro-3R-methylisocumarin [3].

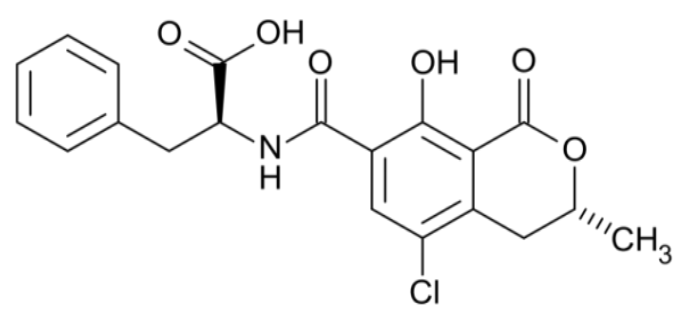

Figure 1- OTA chemical composition [3]

Evidence has shown that OTA is produced predominantly by the Aspergillus (A. ochraceus, A. carbonarius) and Penicillium (P. verrucosum) genus members [2].

The OTA is commonly present in a variety of food items [4] and in a wide range of products (cereals, beans, groundnuts, spices, dried fruits, coffee, etc.) and may be present in milk, liver, kidney, and poultry meat from animals fed with contaminated food due to a carry-over effect [5], which has been observed in all animal species, mainly affecting the kidneys, liver and cardiovascular system [2].

During pregnancy and/or adolescence, the ingestion of foods contaminated with OTA is thought to cause testicular DNA lesions that could be promoted to testicular cancer by puberty [6].

OTA exposure can lead to genotoxicity and carcinogenicity in the formation of DNA adducts. It now seems that OTA may be "a complete carcinogen" rather than a promoter alone (i.e., it has an initiator and promoter activity) [7].

Some studies have discussed the oxidative action of OTA in the brain regions during the stages of nervous system development [8]. Other studies have stated that OTA has induced renal failure with hydronephrosis, decreased weight, decreased red blood cells, decreased hemoglobin concentration, and decreased total protein synthesis in chicken [9], and OTA causes extreme anemia and white blood cell deficiency [10].

In animals and humans, OTA has been shown to be nephrotoxic, hepatotoxic, embryotoxic, teratogenic, neurotoxic, immunotoxic, genotoxic and carcinogenic [7] and [11].

In 1993, the OTA was listed as a potential human carcinogen (group 2B) according to the International Agency for Research on Cancer [12], and one of the most important deleterious mycotoxins [13].

Nanotechnology is a technology that deals with nanoscale materials for different purposes. Nanoparticles (NPs) are usually atomic clusters ranging in size from 1-100 nm and show new and improved properties according to their size, distribution and morphology compared to larger particles of the bulk materials from which nanoparticles are produced [14]. 
The enhanced bioactivity of these tiny particles is due to their high surface area to volume ratio [15]. The increase in the surface area of the NPs relative to their size has provided the wonderful efficacy of these particles in their chemical reaction and biological activity [16].

Approaches to nanotechnology seem to be a promising, reliable and low-cost way of limiting the health effects of mycotoxins. Three key strategies are used in research: inhibition of mold, adsorption of mycotoxins, and reduction of toxic effects by nanoparticles [1].

In general, adsorptive compounds can be used to reduce the effectiveness of mycotoxin [17].

The first development of nanotechnological applications for the removal or detection of mycotoxins has been carried out in 2009 [18].

Nanoparticles of zinc oxide ( $\mathrm{ZnO} \mathrm{NPs}$ ) have an impressive physical and antimicrobial properties and are therefore very helpful to enhance agriculture [15].

Present scientific evidence indicates that there is no or a marginal possible hazard to public health from the use of $\mathrm{ZnO} \mathrm{NP} \mathrm{[19]} \mathrm{since} \mathrm{it} \mathrm{is} \mathrm{reported} \mathrm{as} \mathrm{non-toxic} \mathrm{[20].}$

$\mathrm{ZnO}$ is officially classified by the Food and Drug Administration as a "generally recognized as safe (GRAS)" substance and is also used as a food additive. $\mathrm{ZnO}$ nanostructures show high catalytic efficiency and a strong ability to adsorb and are used more commonly in the manufacturing of sunscreens. Zinc oxide nanoparticles ( $\mathrm{ZnO}$ NPs) have their own value, most preferentially, among various metal oxide nanoparticles, due to their wide range of applications [21].

Due to their special nano-properties, including outstanding bioavailability, ZnO NPs should be more advantageous [22].

Titanium oxide nanoparticles $\left(\mathrm{TiO}_{2} \mathrm{NPs}\right)$ have a protective effect on the cells of the body, as they are particularly susceptible to ultraviolet radiation absorption and the reduction of adverse skin effects [23].

It has been reported that $\mathrm{TiO}_{2} \mathrm{NPs}$ are characterized by their high inhibition capacity and heat tolerance against both pathological bacterial strains and fungi [24], so they play an important role in microbial inhibition [16]. $\mathrm{TiO}_{2}$ is a substance that is humane and environmentally safe. Despite the high chemical stability of $\mathrm{TiO}_{2}$, its' chemical activity increases dramatically and significantly when exposed to a light source such as ultraviolet radiation. This phenomenon identified as photoactivity [25].

\section{Materials and Methods:}

Standard OTA was purchased from Sigma-Aldrich,UK. the OTA quantitatively transferred using deionised water by $1 \mathrm{ml}$ syringe to $100 \mathrm{ml}$ volumetric flask, this process was repeated 20 times to ensure that all the quantity of the OTA transferred to the volumetric flask, the flask was then completed to the required volume with deionised water, the flask was closed, and shook well to ensure homogenization. The resultant solution diluted to 30ppb standard solution and has been checked with HPLC.

The ZnO NPs of $15 \mathrm{~nm}$ particle size were purchased from US Research Nanomaterials, Inc., USA. Here and after, it is denoted $[\mathrm{ZnO}]_{\mathrm{a}}$. The $\mathrm{ZnO}$ NPs of $70 \mathrm{~nm}$ particle size were purchased from Hongwu International Group Ltd., China. Here and after,it is denoted $[\mathrm{ZnO}]_{\mathrm{b}}$. The $\mathrm{TiO}_{2} \mathrm{NPs}$ of $15 \mathrm{~nm}$ particle size were purchased from Skyspring Nanomaterials, Inc., USA. These are denoted $\left[\mathrm{TiO}_{2}\right]_{\mathrm{a}}$. The $\mathrm{TiO}_{2} \mathrm{NPs}$ of $70 \mathrm{~nm}$ particle size were purchased from Hongwu International Group Ltd., China, denoted as $\left[\mathrm{TiO}_{2}\right]_{\mathrm{b}}$

The materials and particle size were tested using the XRD and AFM technique. Then the hydrosols prepared by adding deionised water to the nanomaterials to make different concentration (20, 40, 60, and $80 \mathrm{ppm})$ [26].

The standard OTA suspension was treated with different concentrations of the nanomaterials $\left([\mathrm{ZnO}]_{\mathrm{a}},[\mathrm{ZnO}]_{\mathrm{b}},\left[\mathrm{TiO}_{2}\right]_{\mathrm{a}}\right.$, and $\left.\left[\mathrm{TiO}_{2}\right]_{\mathrm{b}}\right)$ in $1: 1$ ratio [26]. The treated samples were tested for the concentration of OTA using the HPLC technique to compare the concentration of OTA 
before and after treatment, and FTIR technique was employed to understand the molecular changes before and after treatment.

\section{Result and Discussion:}

After treating ochratoxin A with nanomaterials, the samples were examined for the concentration of the ochratoxin A with the HPLC device (this was done in the Ministry of Science and Technology) where it is characterized by its high efficiency and accuracy of the results, even if the concentrations are very low. HPLC is the technique most commonly used for determination of OTA. It is also well suited for analysis of complex matrices (animal feed, coffee beans, animals' kidney, blood, and milk) [5]. The standard sample of OTA with known concentration of $30 \mathrm{ppb}$ was tested as in Figure 2

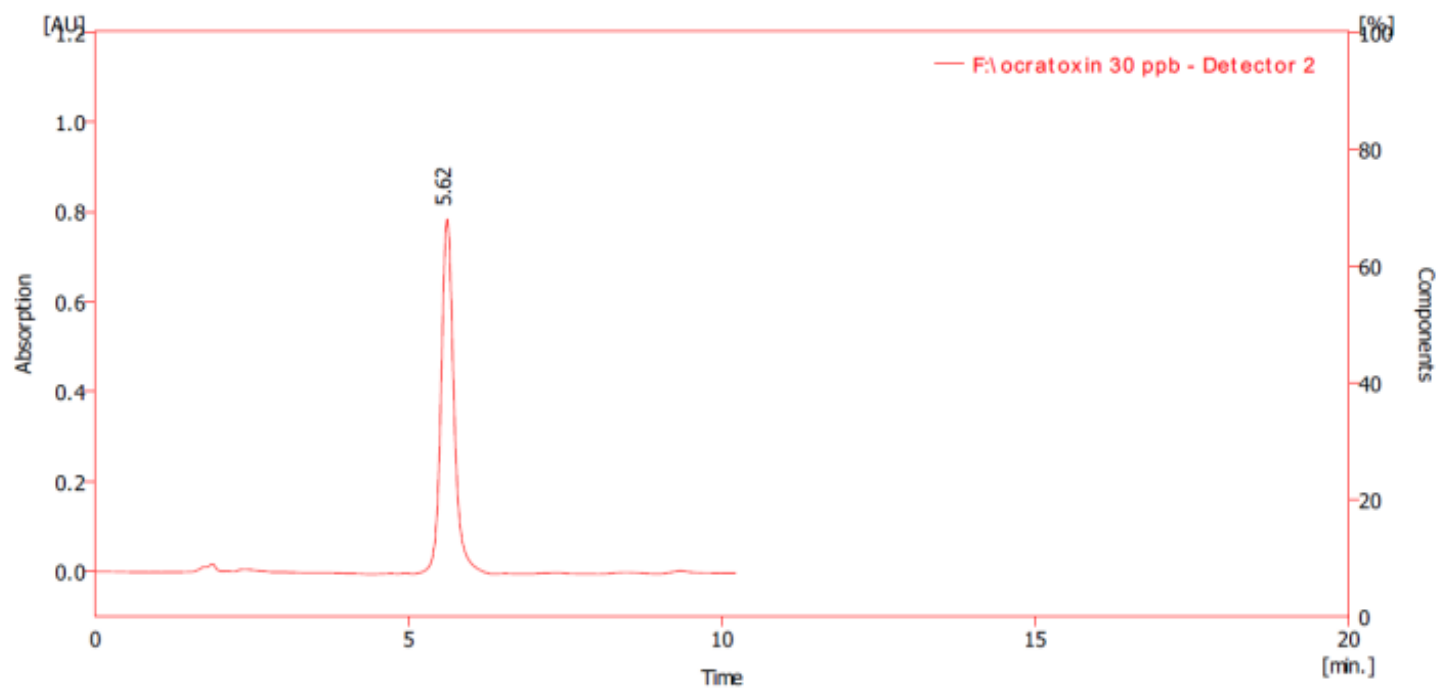

Figure 2-HPLC for $30 \mathrm{ppb}$ OTA standard sample

The treated samples with NPs were tested in a set of 4 samples according to the nanomaterial used with a specific particle size. Figure 3 represents the samples treated with $[\mathrm{ZnO} \mathrm{NPs}]_{\mathrm{a}}$ with concentrations of $20,40,60$, and $80 \mathrm{ppm}$.

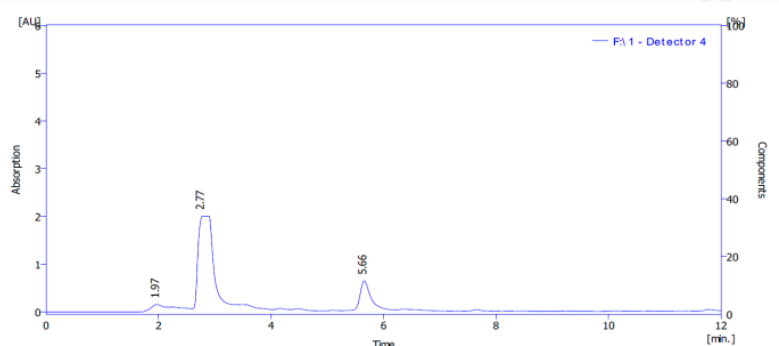

(a)

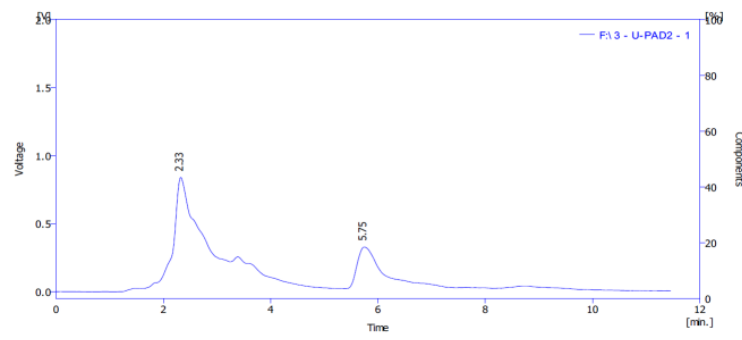

(c)

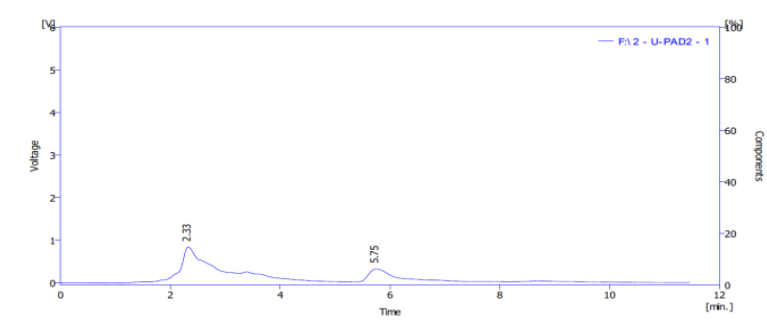

(b)

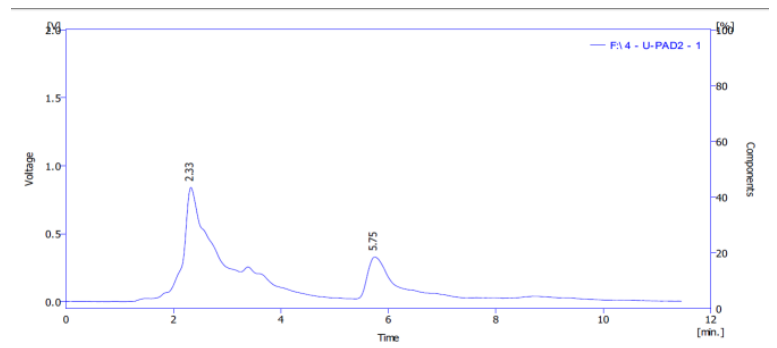

(d)

Figure 3-HPLC results for OTA treated with $[\mathrm{ZnO} N P s]_{\mathrm{a}}$ : (a) $20 \mathrm{ppm}$ of $[\mathrm{ZnO} \mathrm{NPs}]_{\mathrm{a}}$, (b) $40 \mathrm{ppm}$ of $\left[\begin{array}{ll}\mathrm{ZnO} & \mathrm{NPs}\end{array}\right]_{\mathrm{a}}, \quad(\mathrm{c}) \quad 60 \mathrm{ppm} \quad\left[\begin{array}{lllll}\mathrm{ZnO} & \mathrm{NPs}\end{array}\right]_{\mathrm{a}}, \quad(\mathrm{d}) \quad 80 \mathrm{ppm} \quad\left[\begin{array}{lll}\mathrm{ZnO} & \mathrm{NPs}\end{array}\right]_{\mathrm{a}}$. Figure 4 represents the samples treated with $[\mathrm{ZnO} N P s]_{b}$ with concentrations of 20, 40, 60 , and $80 \mathrm{ppm}$. 

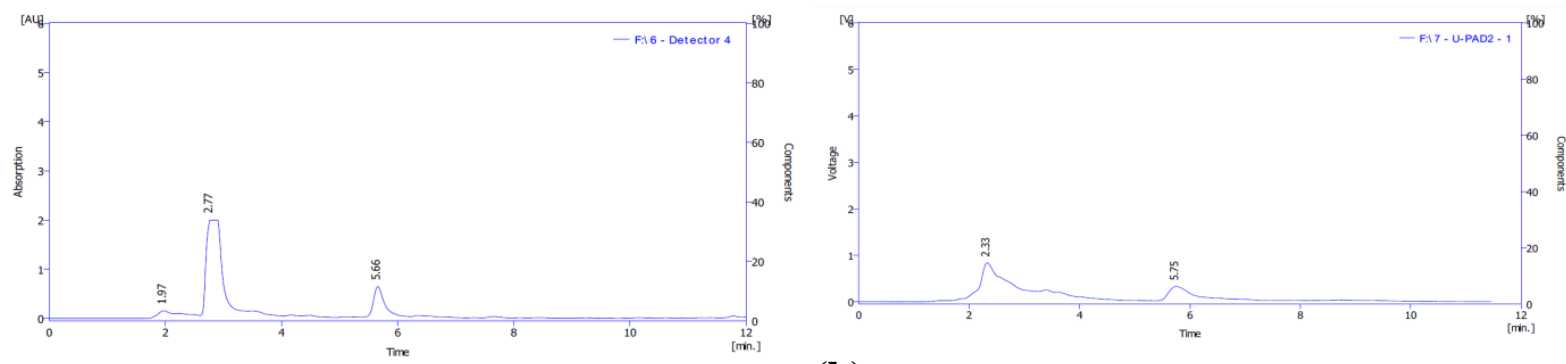

(a)

(b)
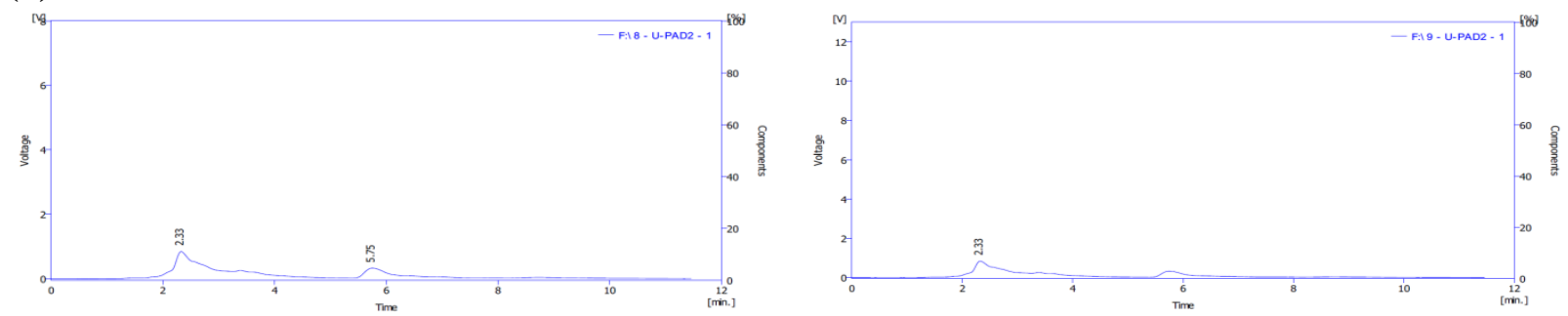

(c)

(d)

Figure -4 HPLC results for OTA treated with [ZnO NPs $]_{b}$ : (a) 20 ppm of [ZnO NPs $]_{b}$, (b) 40 ppm of [ZnO NPs $]_{b}$, (c) 60 ppm of [ZnO NPs $]_{b}$, (d) 80 ppm of [ZnO NPs $]_{b}$.

Figure 5 represents the samples treated with $\left[\mathrm{TiO}_{2} \mathrm{NPs}\right]_{\mathrm{a}}$ with concentrations of $20,40,60$, and $80 \mathrm{ppm}$.
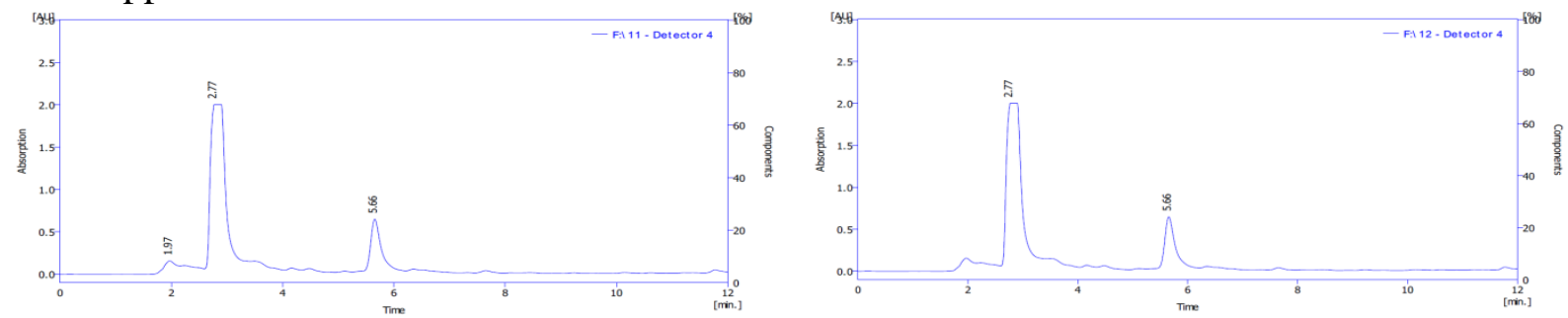

(a)

(b)

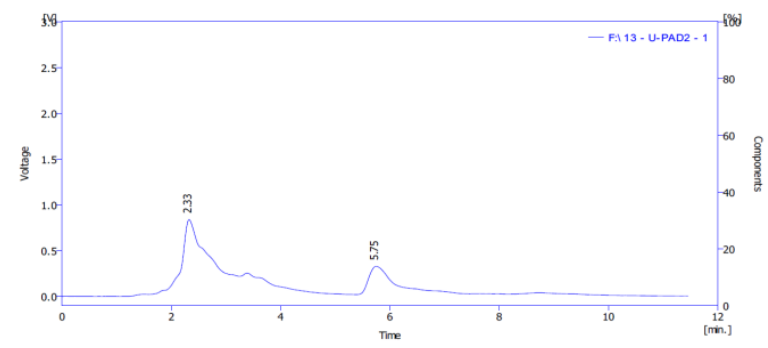

(c)

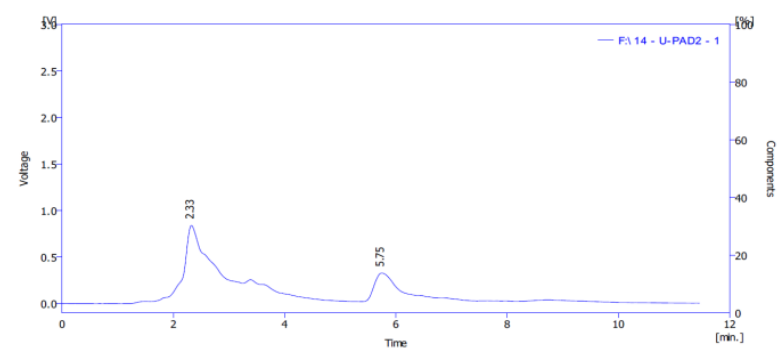

(d)

Figure -5 HPLC results for OTA treated with $\left[\mathrm{TiO}_{2} \mathrm{NPs}\right]_{\mathrm{a}}$ : (a) $20 \mathrm{ppm}$ of $\left[\mathrm{TiO}_{2} \mathrm{NPs}_{\mathrm{a}}\right.$, (b) 40 ppm of $\left[\mathrm{TiO}_{2} \mathrm{NPs}\right]_{\mathrm{a}}$, (c) $60 \mathrm{ppm}$ of $\left[\mathrm{TiO}_{2} \mathrm{NPs}\right]_{\mathrm{a}}$, (d) $80 \mathrm{ppm}$ of $\left[\mathrm{TiO}_{2} \mathrm{NPs}\right]_{\mathrm{a}}$.

Figure 6 represents the samples treated with $\left[\mathrm{TiO}_{2} \mathrm{NPs}\right]_{\mathrm{b}}$ with concentrations of 20, 40, 60 , and $80 \mathrm{ppm}$.
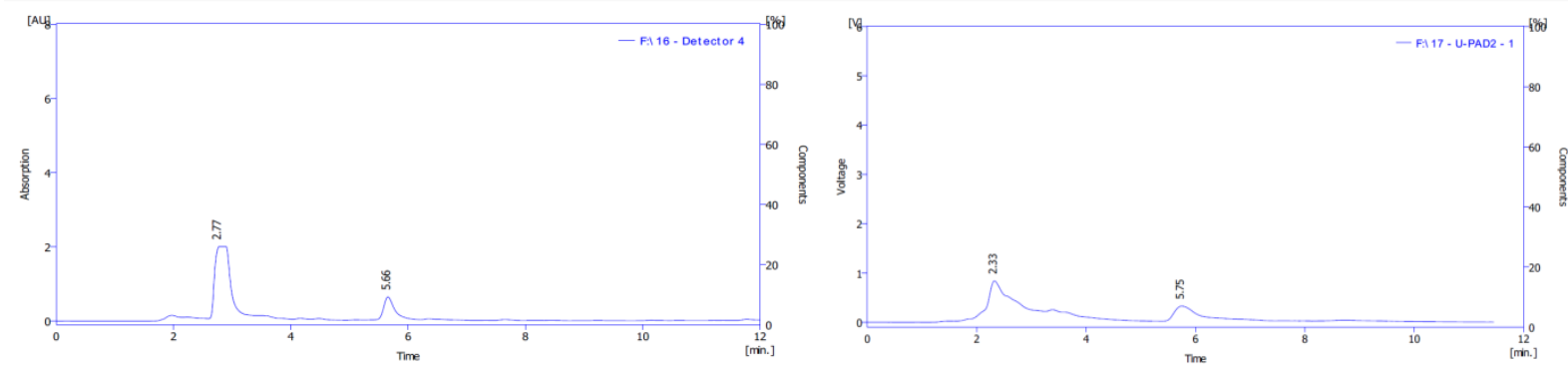

(a)

(b) 


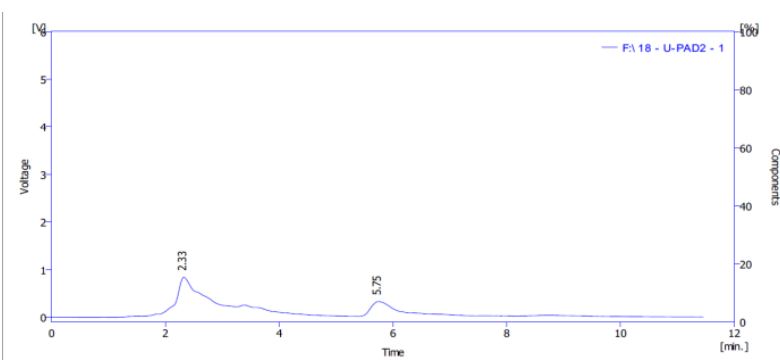

(c)

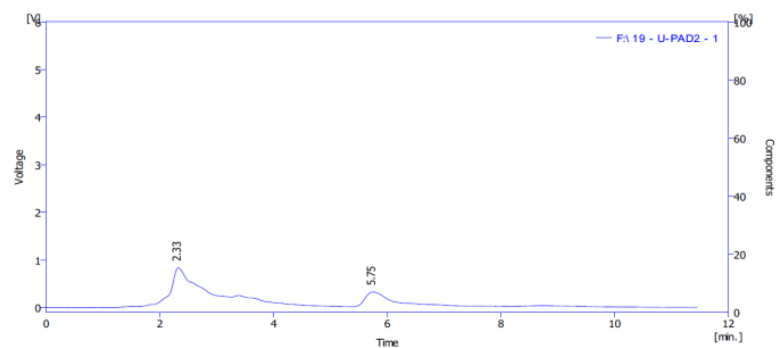

(d)

Figure -6 HPLC results for OTA treated with $\left[\mathrm{TiO}_{2} \mathrm{NPs}\right]_{\mathrm{b}}$ : (a) $20 \mathrm{ppm}$ of $\left[\mathrm{TiO}_{2} \mathrm{NPs}\right]_{\mathrm{b}}$, (b) 40 ppm of $\left[\mathrm{TiO}_{2} \mathrm{NPs}\right]_{\mathrm{b}}$, (c) $60 \mathrm{ppm}$ of $\left[\mathrm{TiO}_{2} \mathrm{NPs}\right]_{\mathrm{b}}$, (d) $80 \mathrm{ppm}$ of $\left[\mathrm{TiO}_{2} \mathrm{NPs}\right]_{\mathrm{b}}$.

The results showed a decrease in the concentration of OTA with the increase of NPs concentration which is agreed with other researchers [27], as they detected that as the concentration of $\mathrm{ZnO}$ NPs increased, the mycotoxin contents of animals feed were decreased till complete elimination.

Figure 7 shows the relation between the treated OTA concentrations with the increase of NPs. concentration

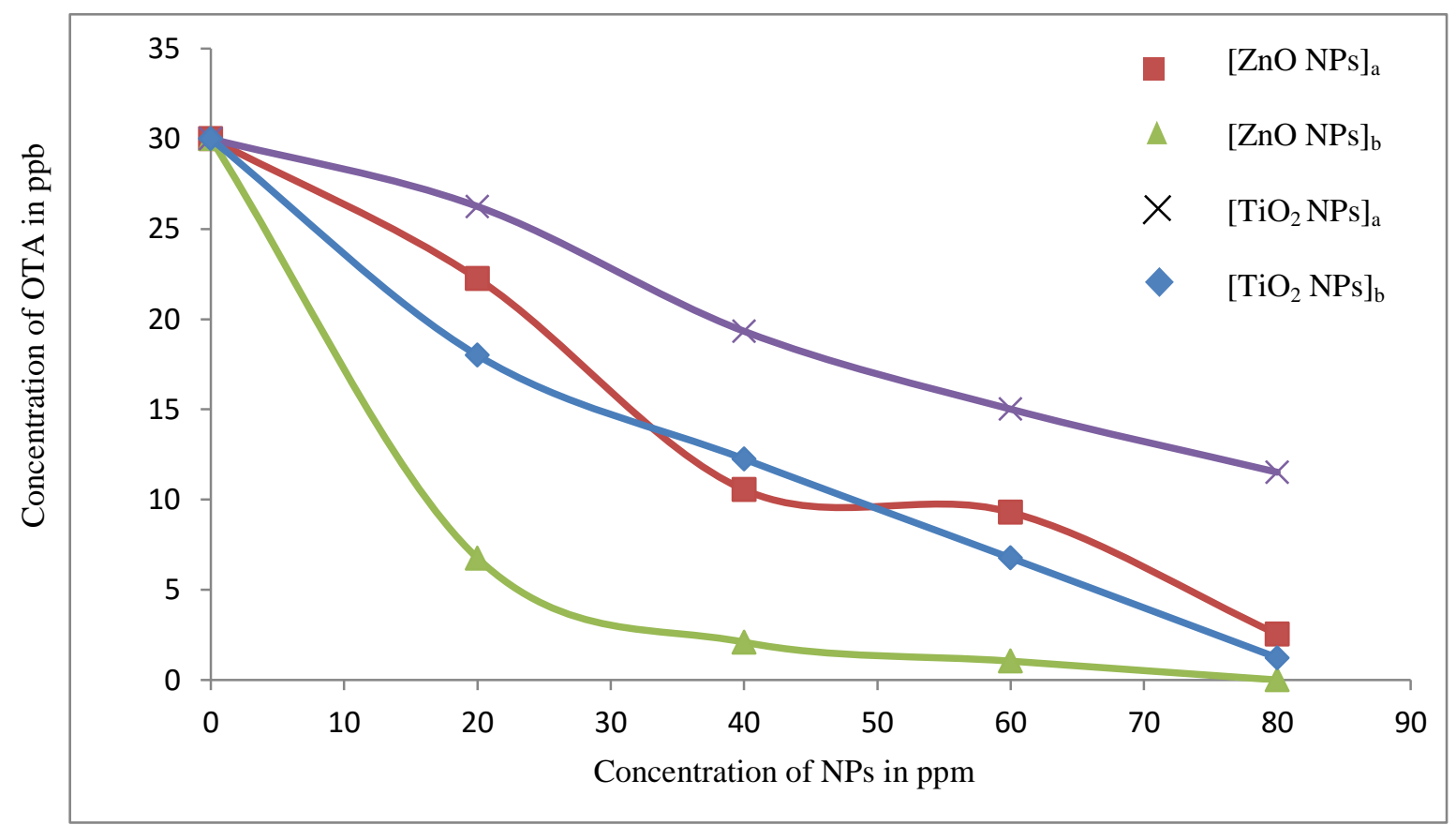

Figure 7-The effect of nanomaterials' concentration on OTA concentration

Tables 1, 2, 3, and 4 reveals these results

Table 1- The percentage reduction of OTA using [ $\mathrm{ZnO} N P s]_{\mathrm{a}}$ in different concentrations

\begin{tabular}{ccc}
\hline$[\mathbf{Z n O} N P s]_{\mathbf{a}}$ Concentration & OTA Concentration with[ZnO NPs $]_{\mathbf{a}}$ & Reduction \\
\hline 0 & 30 & 0 \\
20 & 22.25 & 25.84 \\
40 & 10.55 & 64.84 \\
60 & 9.30 & 69.01 \\
80 & 2.55 & 91.51 \\
\hline
\end{tabular}


Table 2- The percentage reduction of OTA using [ZnO NPs $]_{b}$ in different concentrations

\begin{tabular}{ccc}
\hline$[\mathbf{Z n O} \text { NPs }]_{\mathbf{b}}$ Concentration & OTA Concentration with $[\mathbf{Z n O} \mathbf{N P s}]_{\mathbf{b}}$ & Reduction \% \\
\hline 0 & 30 & 0 \\
20 & 6.75 & 77.49 \\
40 & 2.10 & 93.01 \\
60 & 1.04 & 96.52 \\
80 & 0.00 & 100.00 \\
\hline
\end{tabular}

Table 3- The percentage reduction of OTA using [ $\left.\mathrm{TiO}_{2} \mathrm{NPs}\right] \mathrm{a}$ in different concentrations

\begin{tabular}{ccc}
\hline$\left[\mathbf{T i O}_{\mathbf{2}} \mathbf{N P s}_{\mathbf{a}}\right.$ Concentration & OTA Concentration with $\left[\mathrm{TiO}_{\mathbf{2}} \mathbf{N P s}_{\mathbf{a}}\right.$ & Reduction \\
\hline 0 & 30 & 0 \\
20 & 26.25 & 12.50 \\
40 & 19.33 & 35.57 \\
60 & 15.01 & 49.96 \\
80 & 11.52 & 61.61 \\
\hline
\end{tabular}

Table 4- The percentage reduction of OTA using $\left[\mathrm{TiO}_{2} \mathrm{NPs}\right] \mathrm{b}$ in different concentrations

\begin{tabular}{lll}
\hline$\left[\mathrm{TiO}_{2} \mathrm{NPs}\right]_{\mathrm{b}}$ Concentration & OTA Concentration with $\left[\mathrm{TiO}_{2} \mathrm{NPs}\right]_{\mathrm{b}}$ & Reduction $\%$ \\
\hline 0 & 30 & 0 \\
20 & 18.00 & 40.01 \\
40 & 12.25 & 59.17 \\
60 & 6.76 & 77.46 \\
80 & 1.23 & 95.89 \\
\hline
\end{tabular}

To understand the mechanism of what happened to OTA ochratoxin A after the treatment with the NPs, two samples of different materials were tested with the FT-IR technology in addition to the standard sample of OTA, as shown in Figure 8.

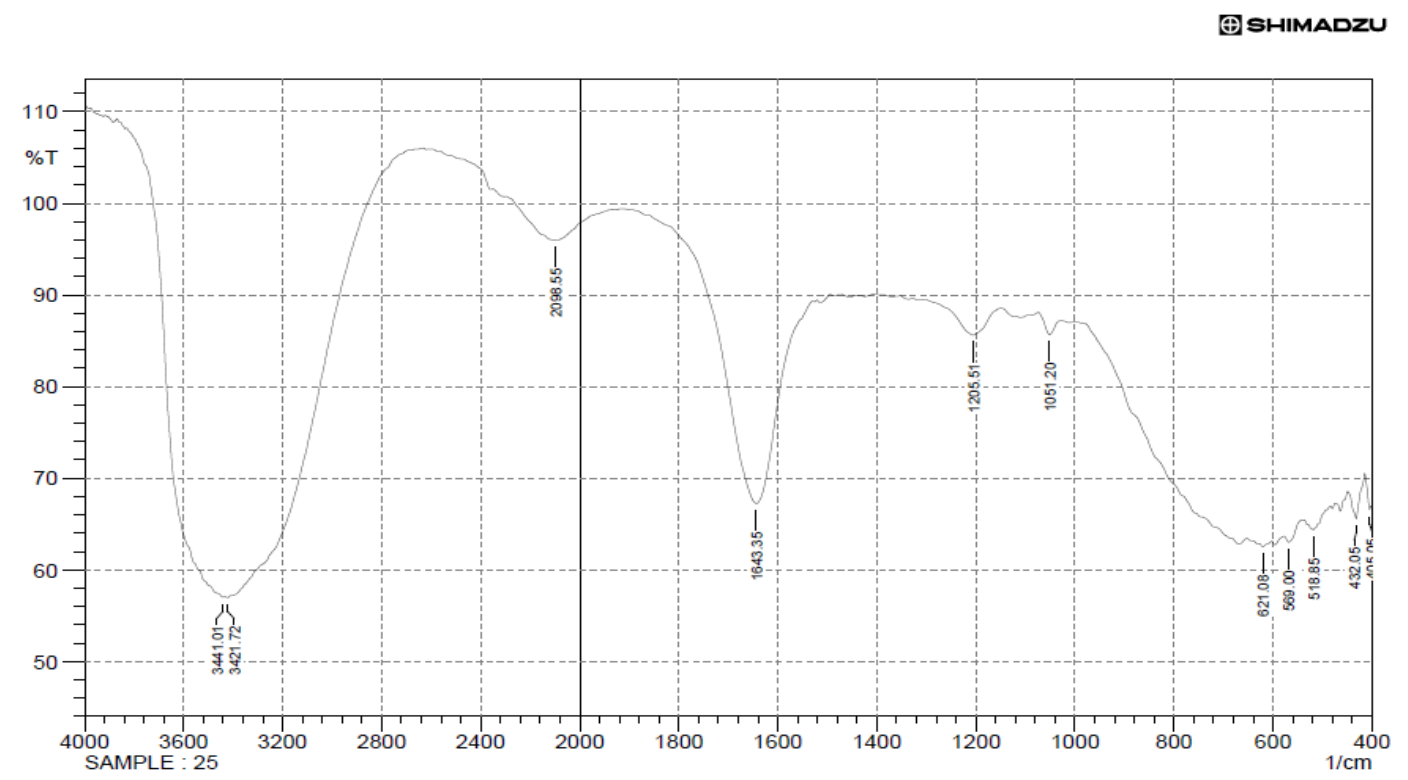

Figure 8 FT-IR result for standard OTA

Figure 9-represents the result of FT-IR of OTA before and after treatment with ZnO NPs and $\mathrm{TiO}_{2}$ NPs. 


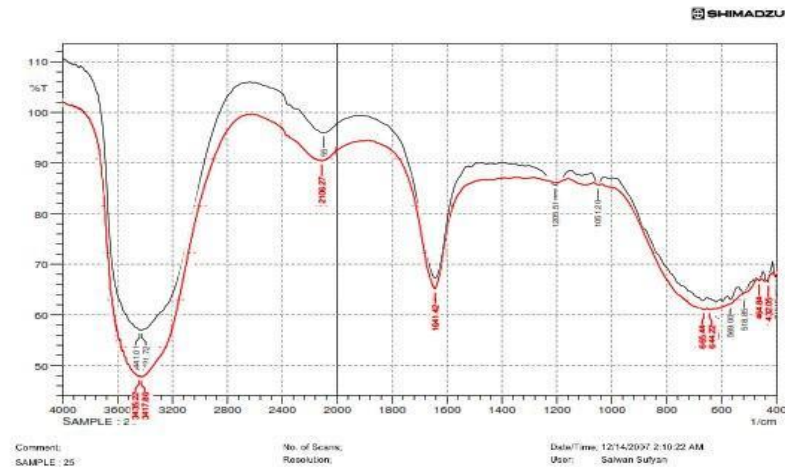

(a)

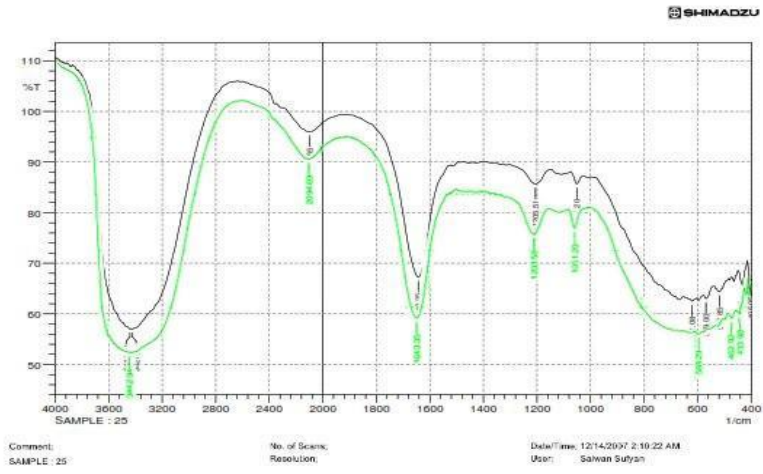

(b)

Figure 9-Comparison between FT-IR of OTA before and after treating with NPs: (a) ZnO $\mathrm{NPs}$, (b) $\mathrm{TiO}_{2} \mathrm{NPs}$

As shown in these figures there was no significant changes in the behavior of the OTA, so it is suggested that the elimination of OTA that represented in the HPLC results occurred by the adsorption with NPs.

Adsorption plays a very significant function in the elimination of mycotoxin. Several studies have shown that NPs can also interfere through an adsorption phenomenon in the detoxification of mycotoxins [28].

At the nanoscale, the NPs are mycotoxin-adsorbing agents that can bind and inhibit gastrointestinal tract mycotoxin uptake [29]. As dietary additives, various NPs are currently used to bind or mitigate the harmful effects of mycotoxins through adsorption in livestock. Some NPs showed a high mycotoxin removal efficiency against OTA [30] due to their specific characteristics of their small size, high surface area-to-volume ratio, surface charge, high catalytic efficiency, stronger adsorbing ability, which allows them to bind to mycotoxins and exhibit higher absorption efficiencies [31], thus the adsorption process could thus be used for the detoxification of mycotoxin in poultry feed [30].

The reduction of mycotoxins by metallic oxide NPs was explained by some researchers as the electrostatic attraction between the negatively charged analytes $\left(\mathrm{COO}^{-}\right)$and the positively charged metal [29], as the electron transfer between the materials was accelerated by $\left(\mathrm{Zn}^{2+}\right.$ and $\mathrm{Ti}^{4+}$ ) from $\mathrm{ZnO}$ and $\mathrm{TiO}_{2}$. Zinc and titanium cations can form coordinated and electrostatic bonds with the OTA's $\beta$-dicarbonyl system, resulting by the high absorption capacity of the NPs used.

In comparison with $\mathrm{TiO}_{2} \mathrm{NPs}$, the high adsorption potential of $\mathrm{ZnO}$ NPs for the OTA can be summarized in two factors: (1) The ZnO NPs do not require UV light for activation. It operates under natural or even diffused sunlight [32] in contemporary with the $\mathrm{TiO}_{2} \mathrm{NPs}$, considering its high chemical stability, it has a chemical photoactivity when exposed to a light source such as ultraviolet radiation [25]. (2) Due to the nature of $\mathrm{TiO}_{2} \mathrm{NPs}_{\text {shen }}$ dispersed in aqueous solutions, in most cases, they tend to form agglomerates [33] while this case dose note reported for the $\mathrm{ZnO}$ NPs.

\section{Conclusion:}

Little research has so far investigated the effect of nanomaterials on mycotoxins directly, but most studies indicated the effect of nanomaterials on fungi and thus inhibit the toxin formed

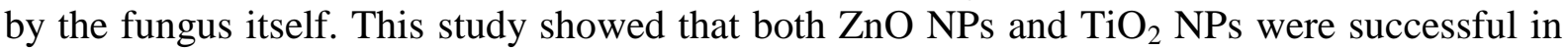
decreasing OTA concentration through adsorption between nanomaterials and toxin molecules. It was also noted that $\mathrm{ZnO}$ NPs were more effective than $\mathrm{TiO}_{2} \mathrm{NPs}_{\text {because of }}$ their surface efficacy and because Zn electronegativity is greater than that of $\mathrm{Ti}$.

Approaches to nanotechnology tend to be a promising, reliable and low-cost way to reduce the health effects of mycotoxins, so it is recommended that this technique be used for feed and 
food treatment as a means of reducing the risk of mycotoxins in humans and animal

\section{Reference}

[1] Horkey P, Skalickova S, Baholet and Skladanka J, "Nanoparticles as a solution for eliminating the risk of mycotoxins," Nanomaterials, vol. 8, no. 9, p. 727, 2018.

[2] Pleadin J, Frece J and Markov K, Chapter eight-"Mycotoxins in food and feed," in Fidel Toldrá (Ed.), Advances in food and nutrition research, vol.89, pp 297-345,2019.

[3] J.L. Richard, "Some major mycotoxins and their mycotoxicoses-An overview," International Journal of Food Microbiology, Vol. 119, No. 1-2, pp. 3-10, 2007.

[4] Gil-Serna J, Vázquez C, Sardiñas N, González-Jaén M T and Patiño B, "Revision of ochratoxin a production capacity by the main species of Aspergillus section Circumdati. Aspergillus steynii revealed as the main risk of OTA contamination," Food Control, vol. 22, no. 2, pp. 343-345, 2011.

[5] Monaci L and Palmisano F, "Determination of ochratoxin A in foods: state-of-the-art and analytical challenges," Analytical and Bioanalytical Chemistry, vol. 378, no. 1, pp. 96-103, 2204.

[6] Schwartz G.G., "Hypothesis: Does ochratoxin A cause testicular cancer?," Cancer Causes \& Control, vol. 13, no. 1, pp. 91-100, 2002.

[7] Dohnal V, Dvořák V, Maliŕ F, Ostrý V and Roubal T , "A comparison of ELISA and HPLC methods for determination of ochratoxin A in human blood serum in the Czech Republic," Food and Chemical Toxicology, vol. 62, pp. 427-341, 2013.

[8] Al-Timimi Z K and Gali M A-H, "Effect of Ochratoxin-A on Mouse Embryos," Baghdad Science Journal, vol. 15, no. 1, pp. 1-8, 2018 .

[9] H. H. Z, "Activity of Pomegranate Peels and Clove Powders in Detoxification of Aflatoxin B1 and Ochratoxin A from Contaminated Poultry Diet," Journal of Plant Pathology \& Microbiology, vol. 6, no. 1, pp. 1-4, 2015.

[10] Ali H and Saied W S, "Individual and combined Effect of Aflatoxine B1 and ochratoxine -A in Broiler Chicken Performance (ISA).," Jornal of Al-Muthanna for Agricultural Sciences, vol. 6, no. 3, pp. 43-48, 2018.

[11] Luo Y, Liu X and Li J , "Updating techniques on controlling mycotoxins - A review," Food Control, vol. 89, pp. 123-132, 2018.

[12] Malir F, Ostry V, Pfohl-Leszkowicz A, Malir J and Toman J, "Ochratoxin A: 50 Years of Research," Toxins, vol. 8, no. 7, p. 191, 2016.

[13] James A and Zikankuba V L, "Mycotoxins contamination in maize alarms food safety in subSahara Africa," Food Control, vol. 90, pp. 372-381, 2018.

[14] Saliem A H, Ibrahim O M and Salih S I , "Biosynthesis of Silver Nanoparticles using Cinnamon zeylanicum Plants Bark Extract," Kufa Journal For Veterinary Medical Sciences, vol. 7, no. 1, pp. 51-63, 2016.

[15] Sabir S, Arshad M and Chaudhari S K , "Zinc Oxide Nanoparticles for Revolutionizing Agriculture: Synthesis and Applications," The Scientific World Journal, vol. 2014, pp. 925494925494, 2014.

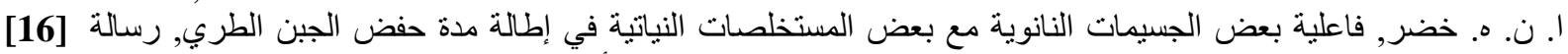

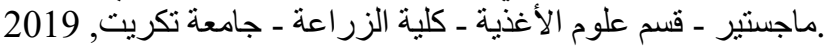

[17] Binder E. M., "Managing the risk of mycotoxins in modern feed production," Animal Feed Science and Technology, vol. 133, no. 1, pp. 149-166, 2007.

[18] Kaushik A, Solanki P R, Ansari A A, Ahmad S and Malhotra B D, "A nanostructured cerium oxide film-based immunosensor for mycotoxin detection," Nanotechnology, vol. 20, no. 5, pp. 55105-55105, 2009.

[19] Sun Q, Li J and Le T , "Zinc Oxide Nanoparticle as a Novel Class of Antifungal Agents: Current Advances and Future Perspectives," Journal of Agricultural and Food Chemistry, vol. 66, no. 43, pp. 11209-11220, 2018.

[20] Ryu H W, Park B S, Akbar S A, Lee W S, Hong K J, Seo Y J, Shin D C, Park J S and Choi G P, "ZnO sol-gel derived porous film for $\mathrm{CO}$ gas sensing," Sensors and Actuators B-chemical, vol. 96, no. 3, pp. 717-722, 2003. 
[21] Wang Z. L, "Functional oxide nanobelts: materials, properties and potential applications in nanosystems and biotechnology," Annual Review of Physical Chemistry, vol. 55, no. 1, pp. 159196, 2004.

[22] Oehlke K, Adamiuk M, Behsnilian D, Gräf V, Mayer-Miebach E, Walz E and Greiner R, "Potential bioavailability enhancement of bioactive compounds using food-grade engineered nanomaterials: a review of the existing evidence," Food \& Function, vol. 5, no. 7, pp. 1341-1359, 2014.

[23] Peira E, Turci F, Corazzari I, Chirio D, Battaglia L, Fubini B and Gallarate M, "The influence of surface charge and photo-reactivity on skin-permeation enhancer property of nano- $\mathrm{TiO} 2$ in ex vivo pig skin model under indoor light," International Journal of Pharmaceutics, vol. 467, no. 1, pp. 90-99, 2014.

[24] Qasem A., "Synthesis of zinc oxide and cobalt oxide nanoparticles in surfactant/antibiotics shell and investigating their anti-bacterial activities" M.Sc.thesis, An-Najah National University, Nablus, Palestine, 2013.

[25] [Online]. Available: http://www.uobabylon.edu.iq/uobcoleges/service_showrest.aspx?fid=21\&pubid=878. [Accessed 118 2021].

[26] Gibson N, Shenderova O, Luo T J M, Fitzgerald Z, Brenner D, Grichko V, Puzyr A, Purtov K and Bondar V , "Nanodiamonds for Detoxification," TechConnect Briefs, vol. 2, no. 2007, pp. 713-716, 2007.

[27] Hassan A A, Sayed-Elahl R M, Oraby N H and El-Hamaky A M. (2020) "Metal nanoparticles for management of mycotoxigenic fungi and mycotoxicosis diseases of animals and poultry," in Mahendra Rai and Kamel A. Abd-Elsalam(Eds.), Nanomycotoxicology - Treating Mycotoxins in the Nano Way, ( pp. 251-269) Academic Press.

[28] Gacem M A, Gacem H, Telli A and Khelil A O E H , "Mycotoxins: decontamination and nanocontrol methods," in Mahendra Rai and Kamel A. Abd-Elsalam(Eds.),Nanomycotoxicology - Treating Mycotoxins in the Nano Way (pp. 189-216) Academic Press.

[29] Udomkun P and Njukwe E.(2020) , Chapter 16-"Nanotechnological methods for aflatoxin control," in Mahendra Rai and Kamel A. Abd-Elsalam(Eds.),Nanomycotoxicology - Treating Mycotoxins in the Nano Way(pp. 385-396) Academic Press. .

[30] Ramadan M M, Mohamed M A, Almoammar H and Abd-Elsalam K A , (2020) Chapter 5"Magnetic nanomaterials for purification, detection, and control of mycotoxins," in Mahendra Rai and Kamel A. Abd-Elsalam(Eds.) Nanomycotoxicology - Treating Mycotoxins in the Nano Way (pp. 87-114) acadmic press.

[31] Adegbeye M J, Elghandour M M, Barbabosa-Pliego A, Monroy J C, Mellado M, Salem A Z, and Reddy P R K, "Nanoparticles in Equine Nutrition: Mechanism of Action and Application as Feed Additives," Journal of Equine Veterinary Science, vol. 78, pp. 29-37, 2019.

[32] Siddiqi K S, Ur Rahman A, Tajuddin, and Husen A, "Properties of Zinc Oxide Nanoparticles and Their Activity Against Microbes," Nanoscale Research Letters, vol. 13, No. 1, p.p. 141, 2018.

[33] Ziental D, Czarczynska-Goslinska B, Mlynarczyk D T, Glowacka-Sobotta A, Stanisz B, Goslinski T and Sobotta L, "Titanium Dioxide Nanoparticles: Prospects and Applications in Medicine," Nanomaterials, vol. 10, No. 2, p.p. 387, 2020. 